\section{Isiaq Olasunkanmi Oseni}

(iD) https://orcid.org/0000-0002-1344-4343

Department of Economics

Faculty of Social Sciences

Olabisi Onabanjo University

Ago-Iwoye, Nigeria

isiaq.oseni@oouagoiwoye.edu.ng

\section{Daniel Akinola Babalola}

https://orcid.org/0000-0002-6557-4617

Department of Agric and Ind Tech

School of Science and Technology

Babcock University, Ilishan-Remo, Nigeria

babalolada@babcock.edu.ng

\author{
Sakiru Oladele Akinbode \\ Department of Economic \\ Federal University of Agriculture \\ Abeokuta, Nigeria \\ deleakinbode13@gmail.com
}

\section{Soliu Bidemi Adegboyega}

Department of Economics

Faculty of Social Sciences

Olabisi Onabanjo University

Ago-Iwoye, Nigeria

adegboyega.soliu@oouagoiwoye.edu.ng

\title{
Government spending and school enrolment in sub-Saharan Africa: A system GMM approach
}

Accepted by Editor Ewa Ziemba | Received: May 28, 2019 | Revised: January 26, 2020; February 21, 2020; February 27, 2020 | Accepted: February 28, 2020.

\begin{abstract}
Aim/purpose - Provision of basic education is pertinent to human capital development, poverty alleviation and abating the threat of insurgence in Africa. Governments in different countries in sub-Saharan Africa (SSA) do budget and spend various amount of money on education every year, but little is known about the effect of such spending on education, especially primary school enrolment which forms the basic educational foundation.

Design/methodology/approach - Using data for 24 countries from 2000 to 2016, this study assesses the effect of government educational spending on primary school enrolment in SSA by employing the System-GMM approach.

Findings - The results show that government spending has significant $(p \leq 0.05)$ and positive effect on primary school enrolment in SSA. The results are further confirmed using different diagnostic tests which include the Arellano-Bond test for first and second order autocorrelation in the disturbance term and the Hansen J-test for the validity of the instrumental variables. Other variables analysed (control), which have positive influence

Cite as: Oseni, I. O., Akinbode, S. O., Babalola, D. A., \& Adegboyega, S. B. (2020). Government spending and school enrolment in sub-Saharan Africa: A system GMM approach. Journal of Economics \& Management, 40(2), 91-108. https://doi.org/10.22367/jem.2020.40.05
\end{abstract}


on enrolment, include GDP, general number of teachers available, and percentage trained teachers. Population growth rate negatively influences enrolment.

Research implications/limitations - The study therefore concludes that increasing spending on education by governments in SSA is sine qua non for improving primary school enrolment rate in the region.

Originality/value/contribution - This study has contributed empirically and theoretically to the body of knowledge. The scope covered also makes the study uniquely robust and different from previous ones, though scanty, country-based assessments.

Keywords: primary school, enrolment, government, expenditure, GMM.

JEL Classification: G30; G32; G38.

\section{Introduction}

The African continent, especially sub-Saharan Africa (SSA), has a great human capital potential which can be harnessed by developing the young people. One out of every six people globally (17\%) is a youth between the age of 15 and 24 and this statistic is expected to increase to one out of every four by 2030 (UN-OSSA, 2018). This global trend is particularly pertinent to Africa because of its largest concentration of the youth. According to UNESCO (2017), UN-OSSA (2018), more than $20 \%$ of Africa's population are the youth below the age of 20 years, making up one fifth of the global youth population. The share of the Africa's youth in the world is forecast to increase to $42 \%$ by 2030 and is expected to continue to grow throughout the remainder of the 21 st century (UN-OSSA, 2018).

The world has gradually progressed into an information age where knowledge plays a critical role in driving economic growth in both the world's most advanced economies and the emerging economies (Anyanwu \& Erhijakpor, 2007). The young people in the continent of Africa are expected to take over the mantle of leadership in the near future and move the continent towards sustainable growth and development. The need to invest in education and capacity development is therefore pertinent to meaningful growth.

It is generally believed that education refines and produces higher quality populace in terms of human capital value addition (Achugbue \& Ochonogor, 2013; Olaniyan \& Okemakinde, 2008). It is perceived as a means of gaining higher incomes which aggregates to higher national income and possibly better condition of living. Investment in education and the formation of human capital are causing rapid growth and development in all the facets of economies all over the world. Sen (1999) viewed development as consisting of free hand to partici- 
pate in political activities in addition to opportunity to receive good health care and basic education among others. The relevance of human capital development (via investment in education) to economic development had been established in the theoretical literature through its indirect contribution to the economic growth or to the promotion of industrialisation (Lucas, 1988; Romer, 1986; Schultz, 2002; Sen, 1999).

After the launch of the Millennium Development Goal-MDG (which was aimed at reducing extreme poverty and ensuring universal basic education worldwide by 2015) in year 2000, many African countries showed serious commitment towards achieving the set goals and many countries in the SSA have taken very important steps aimed at making sure that all school age children get universal primary education by abolishing the payment of school fees. In fact, 15 African countries have abolished payment of school fees in primary schools since the year 2000 (UNICEF, 2015). This has been targeted at ensuring that more children attend primary schools. Generally, despite the increase recorded in school enrolments in the low-income sub-Saharan African countries (AAI, 2015; Anyanwu \& Erhijakpor, 2007; UNESCO, 2009; World Bank, 2012), almost 60 percent of children in sub-Saharan Africa between the ages of 15 and 17 are not at school (UN, 2019). No African country has achieved universal primary education. For a country to achieve this, all concerned children must have completed a full course of primary schooling. In the progress account of the Sustainable Development Goal 4 in 2017, SSA and Southern Asia accounted for over 70 per cent of the global out-of- school population in primary and secondary education (UN, 2019). This situation has become even more critical, especially with the increasing security threats posed by insurgence activities and the recruitment of these out-of-school youths.

Since education provision is very important to promote a broad based economic growth, expenditure on education should be and indeed is considered as a form of investment (Achugbue \& Ochonogor, 2013). However, due to the prevalence of socioeconomic concerns, such as inequality, poverty, inconsistent private financing, cultural heterogeneity, political instability, conflicts, the government of sub-Saharan African countries have roles to play. For instance, the lack of trained teachers and the poor condition of schools in many parts of the world are threatening prospects for quality education for all as captured in the Sustainable Development Goals (SDGs).

In many countries in Africa, education is largely provided by the government as education is widely seen as a public good, especially at the elementary level. Therefore, education expenditure usually takes some proportion of gov- 
ernment spending. However, government resources are usually being competed for by other sectors, such as defence, health, infrastructure, governance. The basis for raising public spending could be traced to theories of public expenditure, such as those of Peacock and Wiseman, Wagner and Musgrave theory of increasing state activities (Obi \& Obi, 2014). These theories all emphasised the need for government spending to enhance economic welfare through its spending in the provision of public goods which are usually seen as non-rival goods. Unfortunately, there is still limited knowledge on the effect of government spending on primary school enrolment in SSA, especially with the employment of up-to-date data capable of revealing the current realities. It is against this backdrop that this study aimed at unearthing the intrinsic relationship between government education spending and primary school enrolment in the region.

Specifically, the study examined the effect of government spending on education in the SSA region and made policy recommendations aimed at improving primary school enrolment. Only few studies have specifically addressed the impact of government education spending on primary school enrolment in subSaharan Africa and their findings have not been consistent (Anyanwu \& Erhijakpor, 2007; Carsamer \& Ekyem, 2015; Obi \& Obi, 2014). Meanwhile, among the available few studies, many predated the existence of the recently adopted the Agenda for Sustainable Development Goals, which was launched in 2015. The main objective of this paper is therefore to contribute to the discussions on the role of government spending on school enrolment, especially in sub-Saharan Africa and on the implication for policy and development. Although the focus of this study, based on the data used, is on primary education, the conclusions are also useful for evaluating education generally and provide a useful framework for future research into other levels of education.

The remainder of the paper is structured thus. In section 2 an empirical review of previous existing studies on the subject matter is provided. In section 3 , an explanation of methodology adopted and data used is given. Section 4 provides the empirical results. Section 5 concludes the paper with the policy implications.

\section{Literature review}

The theoretical underpinning for this study is rational choice theory (RCT) which was first proposed by Adam Smith and was applied to human capital development by Gary (1976). RCT is a framework for understanding and modelling the behaviour of individual actors in an economy. The basic premise of 
rational choice theory is that aggregate social behaviour results from the behaviour of individual actors as they make decisions. The rational choice theory assumes that individuals are rational actors using rational information to try to actively maximise their advantage in any situation and therefore consistently trying to minimise their losses (Akhilesh, 2019). RCT argues that individuals make rational educational decisions that maximise their expected net benefits in terms of income, status, and the avoidance of risk given their socially-specific resources. The theoretical perspective suggests the reduction or eradication of tuition should positively affect enrolment decisions, ceteris paribus, if prospective students are credit constrained (as the case in most African countries) or if they anticipate positive net monetary and non-monetary benefits from education (Kroth, 2015). Therefore, if government provides adequate information and tuition friendly education, a rational individual will likely increase their preference for enrolment of their children in schools.

The relationship between government spending and school enrolment, especially in developing countries, has attracted the interest of several researchers in the past, however, there has been no consensus in their conclusions. Interestingly, most of the studies which utilised panel data, as done in this study, employed Pooled Ordinary Least Square, Fixed Effect Regression, Random Effect and Multinomial regression as estimation techniques among several others with very diverse results. Anyanwu \& Erhijakpor (2007) studied the relationship between government expenditure on education and enrolment, with emphasis on SANE countries (South Africa, Algeria, Nigeria, and Egypt) at the primary and secondary school levels. The study reported positive relationship between government expenditure and school (primary and secondary) enrolment rates. It was further reported that other variables which included national income, democracy and foreign aid to African countries were also important in moving African countries towards the desired progress in school enrolment.

Stasavage (2005) examined the effect of system of governance on provision of public services in Africa and reported that democratically elected African governments spent more on primary education than authoritarian governments, while spending on universities appeared unaffected by system of governance.

Borkum (2012) evaluated the impact of a South Africa fee elimination program. He compared the effect of this program in a poor and wealthy community. The output of this study indicated that increased funding alone is unlikely to lead to higher enrolment, especially in economies that are not credit constrained. 
Using the 2006 Somali Multiple Indicator Cluster Survey (MICS), Moyi (2012) examined and extended the knowledge of the patterns of educational enrolment and attendance in Somalia and identified the major challenges of expanding education access in Somalia. A large difference in the access to schooling in Somalia was reported. Furthermore, access to school was found to be dependent on gender, age and place of residence. Nomads, girls, the poor, and Central-South residents were found to be most disadvantaged.

Carsamer \& Ekyem (2015) investigated the effect of level of governments' educational expenditure on school enrolment at primary and secondary levels using a sample of 20 countries in sub-Saharan Africa over a fifteen-year period. Results indicated that increase in educational expenditure positively increased school enrolment at both primary and secondary school levels. Ojewumi \& Oladimeji (2016) assessed the effect of government expenditure on educational sector in Nigeria, and surprisingly, it was reported that capital expenditure on education and recurrent expenditure had negative effects on the educational sector (school enrolment). Furthermore, Warning \& Durrenberger (2015) using data from 88 developing countries assessed the effect of corruption on schooling (enrolment) and confirmed that corruption negatively correlated with schooling. This brought to the fore the importance of governance effectiveness in ensuring service delivery. The present study is expected to contribute to the literature and come up with unique findings given the use of up-to-date data and novelty of the analytical procedures adopted. This all is expected to foster future research and assist education policy evaluation.

Furthermore, the present study employed the System Generalized Method of Moments (SGMM), two-step robust estimator. This is because in a dynamic panel model the commonly used fixed effects estimator is unreliable when the time span $(\mathrm{T})$ is smaller than the cross-sectional unit $(\mathrm{N})$. The instrumental variable (IV) estimator (Anderson \& Hsiao, 1982) and generalized method of moments (GMM) estimator (Arellano \& Bond, 1991) also suffer from weak instrument problem when the dynamic panel autoregressive coefficient approaches unit in line with the assertion of Blundell \& Bond (1998). According to Oseni (2016), when $\mathrm{T}$ is large, the unweighted GMM estimator is likely to be inconsistent and the efficient two-step estimator may behave in a nonstandard way. Therefore, system GMM two-step robust estimator procedure by Arellano $\&$ Bover (1995) and Blundell \& Bond (1998) were adopted in this paper. 


\section{Research methodology}

Building on the model used by Anyanwu \& Erhijakpor (2007), the present study employed dynamic panel model estimator as proposed by Arellano \& Bover (1995) and developed further in Blundell \& Bond (1998) as explained by Oseni (2016) to examine the relationship between government spending and school enrolment in sub-Saharan African countries using data from 24 SSA countries from 2000 to 2016 . Hence, a dynamic panel regression model to capture the relationship is specified thus:

$$
\begin{aligned}
& P S E_{i t}=\eta+\lambda P S E_{i t-1}+\gamma G S P_{i t}+\sum_{j=1}^{k} \theta X_{j i t}+\varepsilon_{i t} \\
& j=1, \ldots ., k ; i=1, \ldots . ., N ; t=1, \ldots . ., T
\end{aligned}
$$

In equation (1) above, $P S E_{i t}$ represents the regress and (primary school enrolment) for country $i$ in period $t ; P S E_{i t-1}$ was the lagged value of dependent variable for country $i$ over period $t$; GSP $i t$ denotes government spending per year for country $i$ in period $t ; X_{i t}$ is the other regressors included in the model as control variables for country $i$ in period $t$ and $j$ is the number of included control variables. Country specific fixed effect is assumed for the disturbance term, thus:

$$
\varepsilon_{i t}=e_{i}+u_{i t}
$$

where $\varepsilon_{i t}$ represents the error term; $\boldsymbol{e}_{i}$ is the country specific fixed effects that are time invariant;

$$
\boldsymbol{u}_{\mathrm{it}} \approx n\left(0, \sigma_{u}^{2}\right)
$$

The consequence is that the lagged dependent variable depends on the lagged error term and as a result of the correlation, dynamic panel data estimation suffers from bias which disappears only as $t$ tends to infinity. To do away with the country-specific effect, equation (1) can be differenced, thus:

$$
\Delta G P S E_{i t}=\lambda \Delta G P S E_{i t-1}+\gamma \Delta G S P P P_{i t}+\sum_{j=1}^{k} \theta \Delta X_{j i t}+\Delta u_{i t}
$$

Although the transformed error term is correlated with the transformed dependent variable since both contain $u_{i t-1}$, yet this opens up the possibility of using instrumental variable (IV) estimations using the lagged variables as instruments. Hence, this study employed dynamic panel model using system-GMM because it has advantage over difference-GMM in variable that are 'random walk' or close to be random walk (Arellano, 2003; Han, Philip, \& Sul, 2013).

Furthermore, the Sagan or Hansen J-statistic tests were used in performing the tests of over-identifying restrictions. This is to test for the overall validity of the instruments and the null hypothesis is that instruments as a group are exoge- 
nous. Sargan statistic is reported for one-step non-robust estimation which minimized the value of the one-step GMM criterion function. In addition, Hansen J-statistic is reported for one-step robust estimation and for all two-step estimation and minimised the value of the two-step GMM criterion function and it is robust. Based on this criterion, and following Oseni (2016), this study used the Hansen J-statistic to test for over-identifying restrictions.

The description and source of data used for this study are reported in Table 1.

Table 1. Data description and sources

\begin{tabular}{|l|l|l|}
\hline \multicolumn{1}{|c|}{ Data description } & \multicolumn{1}{|c|}{ Proxy } & \multicolumn{1}{|c|}{ Sources } \\
\hline Primary School Enrolment (PSE) & Gross Primary School Enrolment Rate, i.e GPSE & World Bank WDI \\
\hline Corruption Perception Index (CPI) & $\begin{array}{l}\text { CPI }- \text { transparency, accountability, and corruption } \\
\text { in the public sector rating }(1=\text { low to } 6=\text { high) }\end{array}$ & World Bank WDI \\
\hline Real GDP Per Capita (GDPC) & GDP per capita (constant 2010 US\$), i.e GDPC & World Bank WDI \\
\hline Population Growth Rate (PGR) & $\begin{array}{l}\text { Population (children in school) growth (annual \%), } \\
\text { i.e PGR }\end{array}$ & World Bank WDI \\
\hline Price Level (INF) & Inflation, consumer prices (annual \%), i.e INFCPI & World Bank WDI \\
\hline Number of Primary Teachers (NPT) & Primary education, teachers & World Bank WDI \\
\hline $\begin{array}{l}\text { Trained Teachers in Primary School } \\
\text { (TTPS) }\end{array}$ & $\begin{array}{l}\text { Trained teachers in primary education } \\
\text { (\% of total teachers), i.e. TTPS }\end{array}$ & World Bank WDI \\
\hline $\begin{array}{l}\text { Public Educational Expenditure } \\
\text { (GSP) }\end{array}$ & $\begin{array}{l}\text { Government expenditure per student, primary } \\
(\% \text { of GDP per capita), i.e. GSPPP }\end{array}$ & World Bank WDI \\
\hline
\end{tabular}

\section{Research findings/results and discussion}

\subsection{Descriptive statistics, normality test and correlation analysis}

The descriptive statistics which included the minimum, maximum, mean and median of all the study variables are presented in Table 2. Expectedly, all the means and medians lied within the minimum and the maximum values indicating adequate and symmetrical distribution. Judging from the values of the standard deviations, primary school enrolment rate (PSE) and inflation were widely dispersed around their means. Enrolment rate, corruption perception index (CPI) and quality of teachers, which has been represented by trained teachers in primary schools (TTPS), were negatively skewed. 
Table 2. Descriptive statistics and normality test of study variables

\begin{tabular}{|l|r|r|r|r|r|r|r|r|}
\hline \multicolumn{1}{|c|}{ Variables } & \multicolumn{1}{c|}{ GPSE } & \multicolumn{1}{c|}{ CPI } & \multicolumn{1}{c|}{ GSPPP } & \multicolumn{1}{c|}{ INFCPI } & \multicolumn{1}{c|}{ LogGDPC } & \multicolumn{1}{c|}{ LogNPT } & \multicolumn{1}{l}{ PGR } & \multicolumn{1}{c|}{ TTPS } \\
\hline Mean & 96.32 & 2.7139 & 12.3720 & 76.4999 & 6.9366 & 10.7400 & 2.6945 & 77.5430 \\
\hline Median & 97.95 & 3.0000 & 11.2851 & 61.693 & 6.7672 & 10.6523 & 2.6853 & 81.7123 \\
\hline Maximum & 148.12 & 4.0000 & 29.2040 & 24411.03 & 9.2240 & 13.3033 & 5.5391 & 100.0000 \\
\hline Minimum & 32.32 & 1.0000 & 3.6279 & 35.8366 & 5.2671 & 8.4476 & 0.5960 & 39.5761 \\
\hline Std. Dev. & 21.48 & 0.6589 & 5.3109 & 1233.98 & 0.9563 & 1.1399 & 0.7502 & 19.1355 \\
\hline Skewness & -0.073 & -0.3963 & 0.7086 & 19.6403 & 0.8466 & 0.0045 & 0.0202 & -0.3928 \\
\hline Kurtosis & 3.0884 & 2.5583 & 3.1001 & 7.7819 & 2.9622 & 2.3874 & 3.7840 & 1.7465 \\
\hline Jarque-Bera & 0.3894 & 7.8557 & 14.0468 & 2443468. & 47.4479 & 4.4256 & 10.427 & 15.5926 \\
\hline Probability & 0.8230 & 0.1960 & 0.9123 & 0.0000 & 0.0000 & 0.1093 & 0.5000 & 0.4000 \\
\hline Sum & 30726.49 & 621.50 & 2066.13 & 29987.99 & 2753.83 & 3039.43 & 1093.99 & 13259.86 \\
\hline Sum Sq. Dev & 146744.1 & 99.01 & 4682.23 & $5.95 \mathrm{E}+08$ & 362.18 & 366.445 & 227.949 & 62248.48 \\
\hline
\end{tabular}

Note: All acronyms/abbreviations are as defined in Table 1 and below under Table 2 .

Source: Computed from field survey (2018).

The mean and median of all the variables lie between the minimum and maximum values which indicated adequate and symmetrical distribution. The kurtosis statistics revealed that PSE, Government Spending (GSPPP), log of GDP per Capita (LogGDPC) and Population Growth Rate (PGR) were mesokurtic in nature (indicating normal distribution). CPI, Log of number of primary school teacher $(\operatorname{LogNPT})$ and TPS were platykurtic in nature, while inflation was leptokurtic. The results of the Jaque-Berra test considering the probability values revealed that all the variables were normally distributed with no heteroskedasticity (since their probabilities are not significant) except inflation and LogGDPC.

In order to pre-examine the possibility of multicollinearity in the model estimated, the correlation analyses of the model variables was carried out. According to Iyoha (2004), a correlation coefficient of about 0.95 and above portends the danger of multicollinearity in the estimated model. The result of the correlation analyses is presented in Table 3 . The results showed that correlation coefficients between different pairs of variables were low and below the acceptable threshold. This indicated that there was no possibility of multicollinearity in the model to be estimated. 
Table 3. Correlation matrix of study variables

\begin{tabular}{|l|r|r|r|r|r|r|r|r|}
\hline \multicolumn{1}{|c|}{ Variables } & \multicolumn{1}{c|}{ GPSE } & \multicolumn{1}{c|}{ CPI } & \multicolumn{1}{c|}{ GSPPP } & INFCPI & LogGDPC & LogNPT & PGR & TTPS \\
\hline GPSE & 1 & & & & & & & \\
\hline CPI & 0.2925 & 1 & & & & & & \\
\hline GSPPP & -0.5422 & -0.0602 & 1 & & & & & \\
\hline INFCPI & 0.2527 & 0.3389 & -0.3227 & 1 & & & & \\
\hline LogGDPC & 0.0288 & 0.2148 & -0.0106 & 0.1907 & 1 & & & \\
\hline LogNPT & -0.0009 & 0.4407 & 0.1673 & 0.3259 & 0.3876 & 1 & & \\
\hline PGR & -0.5449 & -0.0887 & 0.3260 & -0.2693 & -0.5672 & -0.1957 & 1 & \\
\hline TTPS & 0.00547 & -0.2662 & -0.1380 & -0.0678 & -0.2791 & -0.0285 & 0.05639 & 1 \\
\hline
\end{tabular}

Source: Computed from field survey (2018).

\subsection{Test of stationarity of the study variable}

The study adopted the Levin, Lin and Chu (LLC) t-test to assess whether there was unit root problem among the series (Table 4).

Table 4. Result of unit root test

\begin{tabular}{|l|c|c|c|c|}
\hline \multirow{2}{*}{ Variables } & \multicolumn{2}{|c|}{ Levels } & \multirow{2}{*}{ I(D) } & \multirow{2}{*}{ Autocorrelation } \\
\cline { 2 - 3 } & Level & First difference & & NO \\
\hline PSE & $-9.4661 * * *$ & - & $\mathrm{I}(0)$ & NO \\
\hline GSP & $-8.0791 * * *$ & - & $\mathrm{I}(0)$ & NO \\
\hline CPI & $-4.6339 * * *$ & - & $\mathrm{I}(0)$ & YES \\
\hline INF & $-7.3587 * * *$ & - & $\mathrm{I}(0)$ & NO \\
\hline LogNPT & $-2.8098^{* * *}$ & - & $\mathrm{I}(0)$ & NO \\
\hline LogGDPC & -0.9077 & $-14.0591^{* * *}$ & $\mathrm{I}(1)$ & NO \\
\hline PGR & $-5.8383^{* * *}$ & - & $\mathrm{I}(0)$ & NO \\
\hline TTPS & 6.2067 & $-20.4699^{* * *}$ & $\mathrm{I}(1)$ & \\
\hline
\end{tabular}

Source: Computed from field survey (2018).

It was observed that LogGDPC and TPS were the only variables that were differenced stationary, i.e. not stationary at levels. Other variables (PSE, GSP, CPI, INF, LogNPT and PGR) were stationary at level. Such series are said to have constant means and variances over time and could be used for analyses (especially cause and effect relationship) as they are. 


\subsection{Model results}

The estimated results of the System Generalized Method of Moment (System-GMM) in Table 5 revealed that one year lagged Gross Primary School Enrolment (PSE) had significant and positive effect on present year PSE. This may reflect a behavioural change of parents towards enrolling children for schools possibly coupled with positive effects of government policies and actions which might have culminated into enrolling more children of school ages as at when due over time. This result agrees with Anyanwu \& Erhijakpo (2007). Government spending per primary school pupil represented as percentage of GDP per capita (GSP) had significant (at 5 per cent level) positive relationship with PSE. The result conformed to the a priori expectation. The coefficient value of 0.121 implied that one percent increase in GSP resulted in less than $1 \%$ (0.121 per cent) increase in PSE. This means that government spending is a key driver of primary school enrolment in sub-Saharan Africa. The positive and significant coefficient of government spending reported in this study agrees with the findings of Carsemar \& Ekyem (2015) and Anyanwu \& Erhijakpo (2007) who reported similar findings for Africa, notwithstanding the different years covered by the present study. This result, however, differs from the findings of Iyer (2009) who reported a negative relationship between government spending and school enrolment in India. This confirms the observation of Hanushek (1996) that the relationship between government expenditure and school enrolment may vary from region to region, thus policies should be based on the investigated situation in every region.

If there are no teachers, there would not be anywhere referred to as schools where pupils can learn. Therefore, the a priori expectation holds that teacher's availability is germane to a successful educational system. In line with this assertion, the number of teachers was found to be significant and positively affecting primary school enrolment. Results showed that a per cent increase in the number of primary school teachers employed resulted in 0.73 percent increase in primary school enrolment.

In line with a priori expectation, Population Growth Rate (PGR) (of number of children in the school age) had negative and significant effect on PSE. Results showed that a per cent increase in PGR resulted in 1.19 per cent reduction in PSE in SSA. This finding suggests that as population of the children is growing, the enrolment rate fell and this may be thought of to mean that perhaps the available facilities and human resources have not been able to cope with the growing number of children who are of school age. Furthermore, the habit of withdrawing children from 
school to engage them in child labour in order to provide extra income is common among a large number of households in Africa (The Guardian, 2016). In the same vein, an increase in the proportion of trained teachers (TPS) resulted in 0.72 per cent increase in primary school enrolment (Table 5).

Table 5. Results of system-GMM two-step dynamic panel model

\begin{tabular}{|l|r|r|r|}
\hline \multicolumn{1}{|c|}{ Variables } & \multicolumn{1}{c|}{ Coefficient } & \multicolumn{1}{c|}{ t-Statistics } & \multicolumn{1}{c|}{ P-Value } \\
\hline Lagged Dependent Variable (L1.GPSE) & $0.8929^{* *}$ & 5.98 & 0.0001 \\
\hline CPI & 1.0874 & 0.70 & 0.4940 \\
\hline GSP & $0.1210^{*}$ & 2.40 & 0.0403 \\
\hline INF & 0.0755 & 1.23 & 0.2423 \\
\hline LogNPT & $0.7291^{* *}$ & 2.44 & 0.0161 \\
\hline D(LogGDPC) & 10.5617 & 0.26 & 0.7988 \\
\hline PGR & $-1.1858^{*}$ & -2.32 & 0.0473 \\
\hline D(TPS) & $0.7227^{* *}$ & 3.36 & 0.0079 \\
\hline Constant & $20.3245^{*}$ & 2.83 & 0.0421 \\
\hline
\end{tabular}

Note: Dependent variable: PSE.

Source: Computed from field survey (2018).

\subsection{Post estimation analysis}

Results presented in Table 6 show the test of validity of the instruments employed in the estimation of the system GMM. According to Baltagi (2005), the problem of heteroscedasticity which is common with most variants of the dynamic panel model can be controlled. In testing for the validity of the instrument, it is procedurally important to test for the presence of the first and second order autocorrelation in the disturbance term. Following Arellano \& Bond (1991), it required that there is first order autocorrelation, but there should be no second order autocorrelation. The results in Table 6 show that considering the P-values of the coefficients, there was indeed first order autocorrelation in the disturbance term, while there was no second order autocorrelation because the P-value for AR(1) test was less than 5 per cent suggesting the rejection of the null hypothesis of 'no autocorrelation', while that of AR(2) was more than 5 per cent suggesting the acceptance of the null hypothesis of 'no autocorrelation' in the error term (Table 6). Baum, Schaffer, \& Stillman (2003) explained that the Hansen J-statistic test is the most widely used test in GMM estimation to assess the appropriateness of the instruments employed in the estimation. The F-statistic value further confirmed the overall joint significance of the model (Table 6). 
Table 6. Test of validity of instruments

\begin{tabular}{|l|r|c|}
\hline \multicolumn{1}{|c|}{ Test } & Statistics & P-value \\
\hline Arellano-Bond test for AR(1) & $\mathrm{z}=-2.99$ & 0.0034 \\
\hline Arellano-Bond test for AR(2) & $\mathrm{z}=0.19$ & 0.8610 \\
\hline Hansen J-test & $\mathrm{chi}^{2}(56)=3.93$ & 0.9802 \\
\hline F-test for test of joint significance & 1723.90 & 0.0391 \\
\hline
\end{tabular}

Source: Computed from field survey (2018).

\subsection{Robustness check}

Additional variant of the model was estimated in order to confirm the validity of the system GMM. According to Azeez, Kolapo, \& Ajayi (2012) and Oseni (2016), the value of the coefficient of the lagged dependent variable must be between those obtained from the Pooled Ordinary Least Square (POLS) and the Fixed Effect (FE) estimators. The robustness check results in Table 7 (POLS) and Table 8 (Fixed Effect results) confirmed that the estimated system GMM was valid and correct as it can be observed that coefficient of the System-GMM lied between the values of the FE and the POLS (Tables 7 and 8).

Table 7. Results of the Pooled Ordinary Least Square (POLS) regression

\begin{tabular}{|l|c|c|c|}
\hline \multicolumn{1}{|c|}{ Symbols } & Coefficients & t-value & P-value \\
\hline L1.PSE & 0.9924 & 2.92 & 0.0591 \\
\hline CPI & 0.9801 & 1.43 & 0.3101 \\
\hline GSP & 0.5812 & 3.34 & 0.0073 \\
\hline INF & 0.1925 & 0.98 & 0.3917 \\
\hline LogNPT & 0.3012 & 2.62 & 0.0092 \\
\hline D(LogGDPC) & 4.8120 & 0.93 & 0.4921 \\
\hline PGR & -0.9817 & -2.15 & 0.0182 \\
\hline D(TPS) & 0.5017 & 2.61 & 0.0012 \\
\hline Constant & 12.3451 & 2.28 & 0.0391 \\
\hline Adjusted ${ }^{2}$ & 0.6391 & & \\
\hline F-statistics & 297.34 & & \\
\hline
\end{tabular}

Source: Computed from field survey (2018). 
Table 8. Results of the fixed effect model

\begin{tabular}{|l|c|c|c|}
\hline \multicolumn{1}{|c|}{ Symbols } & Coefficients & t-value & P-value \\
\hline L1.PSE & 0.6419 & 2.18 & 0.0311 \\
\hline CPI & 0.2301 & 2.02 & 0.0430 \\
\hline GSP & 0.3917 & 3.56 & 0.0093 \\
\hline INF & 0.5304 & 0.92 & 0.6320 \\
\hline LogNPT & 0.5402 & 2.61 & 0.0061 \\
\hline D(LogGDPC) & 4.2012 & 2.45 & 0.0401 \\
\hline PGR & -0.0951 & -2.76 & 0.0056 \\
\hline D(TPS) & 0.5824 & 3.01 & 0.0064 \\
\hline Constant & 6.9173 & 2.01 & 0.0262 \\
\hline Adjusted $R^{2}$ & 0.6502 & & \\
\hline F-Statistics & 302.13 & & \\
\hline
\end{tabular}

Source: Computed from field survey (2018).

\section{Conclusions}

Every year in the sub-Saharan African countries, governments have been budgeting and indeed spending a various amount of money on education. The literature abound on the assessment of the impact of government spending on education, especially school enrolment, but results have not been consistent. While some authors have reported positive relationship, others have reported negative relationship and some have found no relationship between the two variables. In addition, most studies adopted pooled ordinary least square estimate (OLS), Fixed effect model, Random effect model among others, while much attention has not been paid to the application of the system generalized method of moments (GMM) dynamic panel two step in assessing the relationship between school enrolment and government spending in sub-Saharan Africa.

Results of the panel analysis revealed that government spending had positive and significant effect on school enrolment. This implied that government spending actually stimulated or encouraged primary school enrolment in SSA. Thus, policy framework that enhances the establishment and maintenance of schools will motivate children to enrol for primary schools close to their houses or not too far away. This may also encourage parents to enrol their children for nearby schools rather than using them for hawking or taking them to farms as it is being practiced in most rural areas in SSA. Previous year's enrolment rate also had positive and significant effect on present year school enrolment. In addition, other control variables, such as the number of primary school teachers, propor- 
tion of trained teacher (teachers' quality), and population growth rate were found to have significant relationship with primary school enrolment in the sub-Saharan African countries. Results of the post estimation diagnosis showed that the model's instruments were valid, no second order autocorrelation and the model is had overall validity.

The study concluded that government spending on education had significant positive effect on primary school enrolment in SSA. The study therefore recommended that governments in SSA countries should further review expenditure pattern to favour more the education sector, especially by striving as much as possible to reach the minimum benchmark set by the United Nations Educational Scientific and Cultural Organization (UNESCO) that countries should spend at least 26 percent of their annual budget on education. Nearly all the countries in the region are members of UNESCO. Such increased funding should be spent on training more teachers, building more schools among other items which will have direct sustainable impact on school enrolment and effective teaching and learning in SSA.

This study did not specifically capture the role and contributions of the private sector and non-government organisations to educational development in SSA, thus future studies should investigate this.

\section{References}

AAI. (2015). State of education in Africa Report 2015: A report card on the progress, opportunities and challenges confronting the African education sector. Retrieved from http://www.aaionline.org/wp-content/uploads/2015/09/AAI-SOE-report-2015-final.pdf

Achugbue, E. I., \& Ochonogor, W. C. (2013). Human capital development through appropriate utilisation of information services. African Research Review, 7(3), 75-85. https://doi.org/10.4314/afrrev.v7i3.6

Akhilesh, G. (2019). Rational choice theory. Retrieved from https://www.investopedia. $\mathrm{com} /$ terms/r/rational-choice-theory.asp

Anderson, T. W., \& Hsiao, C. (1982). Formulation and estimation of dynamic models using panel data. Journal of Econometrics, 18(1), 47-82. https://doi.org/10.1016/ 0304-4076(82)90095-1

Anyanwu, J. C., \& Erhijakpor, A. E. O. (2007). Education expenditures and school enrolment in Africa: Illustrations from Nigeria and other SANE countries (Economic Research Working Paper, No. 92). Abidjan: Africa Development Bank. Retrieved from https://www.afdb.org/fileadmin/uploads/afdb/Documents/Publications/2682 0446-EN-ERWP-92.PDF

Arellano, M. (2003). Panel data econometrics. Oxford: Oxford University Press. 
Arellano, M., \& Bond, S. (1991). Some tests of specification in panel data: Monte Carlo evidence and an application to employment equations. Review of Economics and Statistics, 58, 277-291. https://doi.org/10.2307/2297968

Arellano, M., \& Bover, O. (1995). Another look at the instrumental variables estimation of error components models. Journal of Econometrics, 68, 29-51. https://doi.org/ 10.1016/0304-4076(94)01642-D

Azeez, B. A., Kolapo, F. T., \& Ajayi, L. B. (2012). Effect of exchange rate volatility on macroeconomic performance in Nigeria. Interdisciplinary Journal of Contemporary Research in Business, 4(1), 149-155. Retrieved from https://journalarchieves18.webs.com/149-155.pdf

Baltagi, B. H. (2008). Econometric analysis of panel data. Chichester: John Wiley \& Sons.

Baum, C. F., Schaffer, M. E., \& Stillman, S. (2003). Instrumental variables and GMM: Estimation and testing. Stata Journal, 3(1), 1-31. Retrieved from https://journals. sagepub.com/doi/pdf/10.1177/1536867X0300300101

Borkum, E. (2012). Can eliminating school fees in poor districts boost enrollment? Evidence from South Africa. Economic Development and Cultural Change, 60(2), 359-398. Retrieved from https://www.jstor.org/stable/10.1086/662580

Blundell, R., \& Bond, S. (1998). Initial conditions and moment restrictions in dynamic panel data models. Journal of Econometrics, 87(1), 115-143. https://doi.org/ 10.1016/S0304-4076(98)00009-8

Carsamer, E., \& Ekyem, E. (2015). An empirical analysis of government education expenditure on enrolments at primary and secondary school levels in Africa, International Journal of Economics, Commerce and Management, 3(7), 273-294. Retrieved from http://ijecm.co.uk/wp-content/uploads/2015/07/3717.pdf

Gary, S. B. (1976). The economic approach to human behavior. Chicago: University of Chicago Press. Available at https://books.google.pl/books?id=ci5OCgAAQBAJ\& printsec $=$ frontcover \&dq $=$ Gary,+ S. + B. $+(1976) .+$ The + economic + approach + to + hum an+behavior\&hl=pl\&sa $=$ X\&ved=0ahUKEwjrmbT6-b_pAhUh_SoKHaTzB14Q6A EIKzAA\# $\mathrm{v}=$ onepage $\& \mathrm{q} \& \mathrm{f}=$ false

Han, C., Phillips, P. C. B., \& Sul, D. (2013). X-differencing and dynamic panel model estimation. Econometric Theory, 30(1), 201-251. https://doi.org/10.1017/S02664 66613000170

Hanushek, E. A. (1996). School resources and student performance. In G. Burtless (Ed.), Does money matter? The effect of school resources on student achievement and adult success (pp. 43-73). Washington, DC: Brookings Institution Press.

Iyer, T. (2009). Is public expenditure on primary education effective? Evidence from districts across India. Thesis submitted to the Department of Economics, Trinity College of Duke University, Durham, North Carolina.

Iyoha, M. A. (2004). Applied econometrics (Second edition). Benin City, Nigeria: Mindex Publishing. 
Kroth, A. J. (2015). The effects of the introduction of tuition on college enrollment in Germany: Results from a natural experiment with special reference to students from low parental education backgrounds (Doctoral thesis, University of Michigan, Ann Arbor, MI). Retrieved from https://deepblue.lib.umich.edu/bitstream/handle /2027.42/111597/ankroth_1.pdf

Lucas, R. E. (1988). On the mechanics of economic development. Journal of Monetary Economics, 22(1), 3-42. https://doi.org/10.1016/0304-3932(88)90168-7

Moyi, P. (2012). Who goes to school? School enrollment patterns in Somalia. International Journal of Educational Development, 32(1), 163-171. https://doi.org/10.1016 /j.ijedudev.2010.09.002

Obi, Z. C., \& Obi, C. O. (2014). Impact of government expenditure on education: The Nigerian experience. International Journal of Business and Finance Management Research, 2, 42-48. Retrieved from https://pdfs.semanticscholar.org/1d8d/cd0d2b 0315e71722681fc84c1e674113ea0a.pdf

Ojewumi, J. S., \& Oladimeji, W. O. (2016). Effect of public spending on the growth of educational sector in Nigeria. JORIND, 14(2). Retrieved from https://www. transcampus.org/JORINDV14DEC2016/24.pdf

Olaniyan, D. A., \& Okemakinde, T. (2008). Human capital theory: Implications for educational development. European Journal of Scientific, 24(2), 157-162. Retrieved from http://medwelljournals.com/abstract/?doi=pjssci.2008.479.483

Oseni, I. O. (2016). Exchange rate volatility and private consumption in Sub-Sahara countries: A system-generalized method of moment dynamic panel analysis. Future Business Journal, 2, 103-115. https://doi.org/10.1016/j.fbj.2016.05.004

Romer, P. (1986). Increasing returns and long-run growth. Journal of Political Economy, 94(5), 1002-1037. https://doi.org/10.1086/261420

Schultz, T. P. (2002). Why governments should invest more to educate girls. World Development, 30, 207-225. https://doi.org/10.1016/S0305-750X(01)00107-3

Sen, A. (1999). Development as freedom. New York: Alfred A. Knopf.

Stasavage, D. (2005). Democracy and education spending in Africa. American Journal of Political Science, 45(1), 34-47. https://doi.org/10.1111/j.0092-5853.2005.00127.x

The Guardian. (2016). Child labour is part of most of what we buy today - what can we do? Spotlight on Africa. Retrieved from https://www.theguardian.com/sustainablebusiness/2016/nov/24/child-labour-what-can-we-do-africa-modern-slavery

UN. (2019). Education in Africa. United Nation report. Retrieved from http://uis. unesco.org/en/topic/education-africa

UN-OSSA. (2018). Youth empowerment. New York: Office of the Special Adviser on Africa, United Nation. Retrieved from https://www.un.org/en/africa/osaa/peace/ youth.shtml 
UNESCO. (2009). Education for all global monitoring report. Regional overview for sub-Saharan Africa. New York: United Nations Educational, Scientific and Cultural Organisation. Retrieved from https://en.unesco.org/gem-report/sites/gem-report /files/178418e.pdf

UNESCO. (2017). Education and skills for the 21st century (Working document). Retrieved from http://www.unesco.org/new/fileadmin/MULTIMEDIA/FIELD/Santiago /pdf/Habilidades-SXXI-Buenos-Aires-Eng.pdf

UNICEF. (2015). Education: The case for support. Retrieved from https://www.unicef. org/publicpartnerships/files/UNICEF_Case_for_Support__Education_14Dec2015.pdf

Warning, N., \& Durrenberger, S. (2015). Corruption and education: Does public funding of higher education matter? Annual Conference 2015. Economic Development Theory and Policy. Hamburg: German Economic Association.

World Bank. (2012). Education in Sub-Sahara Africa: A comparative study. Retrieved from http://documents.worldbank.org/curated/en/892631468003571777/pdf/7097 90PUB0EPI0067926B09780821388891.pdf 